\title{
Physicochemical Characteristics of Beef Jerky Cured with Salted-fermented Anchovy and Shrimp
}

\author{
Gap-Don Kim ${ }^{1, a}$, Gwang-woong Go ${ }^{2, a}$, Hyun-Jung Lim³ ${ }^{3}$, Eun-Young Jung ${ }^{4}$, Hyun-Woo Seo ${ }^{4}$, \\ Jin-Yeon Jeong ${ }^{5}$, Seon-Tea $\mathrm{Joo}^{5}$, and Han-Sul Yang ${ }^{4,5, *}$ \\ ${ }^{1}$ Department of Food Science and Biotechnology, Kyungnam University, Changwon 631-701, Korea \\ ${ }^{2}$ The Department of Internal Medicine, Yale University School of Medicine, New Haven, CT 06510, USA \\ ${ }^{3} R \& D$ Center, Seawell, Byeoksan E-Centum Classone, Busan 612-050, Korea \\ ${ }^{4}$ Division of Applied Life Science (BK21 plus), Gyeongsang National University, Jinju 660-701, Korea \\ ${ }^{5}$ Institute of Agriculture \& Life Science, Department of Animal Science, Gyeongsang National University, \\ Jinju 660-701, Korea
}

\begin{abstract}
The aim of this study is to evaluate the availability of salted and fermented fish (SFF) including salted and fermented anchovy (SFA) and shrimp (SFS) as a marinade of beef jerky. In curing solutions, half (SFA 1 and SFS 1) or whole (SFA 2 and SFS 2) salt-water was replaced with SFF juices. Higher water activity $\left(\mathrm{a}_{\mathrm{w}}\right)$ was found in the beef jerky cured with SFFs than the control $(C)(p<0.05)$. The SFFs had the effect of causing a decrease in hardness and an increase in cohesiveness $(p<0.05)$. Among the treatment samples, springiness was the highest in SFA2 and SFS2 $(p<0.05)$ and the lowest values of Warner-Bratzler shear force were found in SFA1 and SFA2 $(p<0.05)$. The SFFs also had the effect of increasing the flavor of the sensory properties; however, color measurements from both the instrumental surface color $\left(\mathrm{L}^{*}, \mathrm{a}^{*}, \mathrm{~b}^{*}\right.$, chroma, and hue angle) and color of sensory evaluation were decreased by addition of SFFs $(p<0.05)$. Therefore, we conclude the SFFs can improve the texture and sensory properties of the beef jerky. In particular, the SFS is a good ingredient for the curing solution. However, studies are still needed on improving the $\mathrm{a}_{\mathrm{w}}, \mathrm{pH}$, and surface color of the beef jerky to apply the SFFs for making beef jerky.
\end{abstract}

Key words: beef jerky, salted-fermented fish, anchovy, shrimp

\section{Introduction}

Jerky is one of the oldest meat products and has been sold for many years in the form of snack foods. Jerky is obtained from sliced whole muscles marinated and dried. Jerky type products are characterized by a diversity of raw materials, spices, and other additives, and by the technological procedures such as curing, smoking, drying, and packaging (Konieczny et al., 2007). With growing and varying consumer preferences for high quality foods with good texture, color, flavor, and nutritional value, few attempts have been made to assess the quality of jerky using various processing techniques such as the marina-

\footnotetext{
${ }^{\mathrm{a}}$ These authors equally contribeted.

*Corresponding author: Han-Sul Yang, Department of Animal Science, Gyeongsang National University, Jinju 660-701, Korea. Tel: 82-55-772-1948, Fax: 82-55-772-1949, E-mail: hsyang@ gnu.ac.kr
}

tion method, the drying condition, and the raw meat conditions (Albright et al., 2003; Calicioglu et al., 2003; Choi et al., 2006; Han et al., 2007; Konieczny et al., 2007; Yang et al., 2009). As snack foods, the sensory qualities including texture, color, and flavor are considered to be the most important attributes of jerky (Konieczny et al., 2007).To improve the qualities of jerky, we introduced the juice of salted and fermented fish (SFF) as the marinade.

The SFF products are popular in South-East Asian countries, such as Korea (Jeotgal), Thailand (Som-fak), China (Suan yu), and Japan (fish nukazuke) (Adams et al., 1985; Ishige, 1993; Kuda et al., 2012; Mah et al, 2002; Zeng et al., 2013). The SFFs are produced by mixing whole fish with $5-20 \%$ of salt for several months at the ambient temperature. The fish fermentation process consists of the transformation of organic substances into simpler compounds such as amino acids, peptides and various nitrogenous compounds (Peralta et al., 2008). SFFs 
and their liquid sauce have been widely utilized in a variety of processed products due to their salty, unique flavor and aroma (Peralta et al., 2008; Tsai et al., 2006). For dried food such as jerky to be shelf stable, low water activity $\left(\mathrm{a}_{\mathrm{w}}<0.85\right)$ and preservatives including salt, organic acids and sodium nitrite are required (Gailani and Fung, 1986). SFF juice contains salt as well as various flavor and aroma compounds.

For these reasons, the beef jerky was prepared by curing with the SFF juice made of anchovy and shrimp, and the quality properties of beef jerky were investigated. The aim of this study is to evaluate the availability of SFF juice as a marinade of beef jerky.

\section{Materials and Methods}

\section{SFF preparation}

Salted and fermented anchovy (SFA) and shrimp (SFS) were purchased at a local retail store in Jinju, Korea on August 2012. Anchovy and shrimp were washed thoroughly and mixed with salt at a ratio of $20 \%$ to raw fish. The mixtures were piled in glass containers and the containers were capped. They were then fermented at room temperature $\left(15-25^{\circ} \mathrm{C}\right)$ for three months. The juices naturally released from SFFs were collected and filtered using a cheese cloth. After filtering, the salinity of the SFF juice was measured using aconductivity meter (CR-30R, TOADKK, Japan) and adjusted to $11.5 \%$ salt using distilled water.

\section{Preparation of beef jerky}

A total of five bovine semimembranosus (BS) muscles $(10 \mathrm{~kg})$ were obtained from cattle (Hanwoo, Korean native cattle) at a commercial slaughterhouse. The BS muscles were dissected from each carcass within $48 \mathrm{~h}$ of postmortem, and their subcutaneous fat and visible connective tis- sue were removed. The BS muscles were sliced to $0.5-\mathrm{cm}$ thick slices using a meat slicer (HFS 350G, Hankook Fujee Industries Co., Ltd., Korea) and cut into pieces of 5.0 $\times 10.0 \times 0.5 \mathrm{~cm}$. All BS slices were divided randomly into five groups (C, SFA1, SFA2, SFS1, and SFS2) and cured with different curing solutions in a cold room $\left(4^{\circ} \mathrm{C}\right)$ for 24 h. Curing solutions for $\mathrm{C}$ consisted of 3.0\% sugar, 3.9\% starch syrup, $0.2 \%$ black pepper, $0.024 \%$ sodium nitrite, and $9.0 \%$ salt-water (based on raw meat weight). The salt-water was prepared by dissolving sodium chloride in distilled water and its salinity adjusted to $11.5 \%$ salt as the same salinity of SFF juice.The curing solutions for treatments were prepared by replacement of half or whole of salt-water by SFA or SFS juice. The formulation of cure solution is presented in Table 1 .

The cured BS muscles were dried in a dryer (DS80-1, Dasol Scientific Co. Ltd., Korea) at $70^{\circ} \mathrm{C}$ for $6 \mathrm{~h}$ to achieve a water activity of 0.83 . After drying, the beef jerky samples were cooled at the ambient temperature.

\section{Water activity $\left(\mathrm{a}_{\mathrm{w}}\right)$ and $\mathrm{pH}$}

The water activity was determined using a water activity meter (AQX-2, Nagy mess system, Germany) calibrated at the ambient temperature $\left(20^{\circ} \mathrm{C}\right)$ with distilled water $\left(\mathrm{a}_{\mathrm{w}}=0.999\right)$ and saturated solution of $\mathrm{NaCl}\left(\mathrm{a}_{\mathrm{w}}=0.756\right)$ and $\mathrm{KCl}\left(\mathrm{a}_{\mathrm{w}}=0.853\right)$. The $\mathrm{pH}$ was analyzed on homogenates of $5.0 \mathrm{~g}$ sample in $45 \mathrm{ml}$ of distilled water using a $\mathrm{pH}$ meter (Model 230, Mettler-Toledo GmbH, Switzerland).

\section{Moisture and protein contents}

The beef jerky samples were cut into small pieces using sharp scissors and samples were analyzed for moisture and protein contents. Moisture content was determined according to the AOAC method (AOAC, 2000). Protein content was analyzed by Kjeldahl procedure using a Kjeldahl nitrogen analyzer (Kjeltec ${ }^{\circledR} 2300$ Analyzer Unit, Foss

Table 1. Formulation of the curing solution for making beef jerky

\begin{tabular}{cccccc}
\hline \hline \multirow{2}{*}{ Ingredients } & \multicolumn{5}{c}{ Treatments } \\
\cline { 2 - 6 } & $\mathrm{C}$ & SFA1 & SFA2 & SFS1 & SFS2 \\
\hline Salt-water & 9.0 & 4.5 & - & 4.5 & - \\
SFA $^{2)}$ & - & 4.5 & 9.0 & - & - \\
SFS $^{3)}$ & - & - & - & 4.5 & 9.0 \\
Sugar & 3.0 & 3.0 & 3.0 & 3.0 & 3.0 \\
Starch syrup & 2.5 & 2.5 & 2.5 & 2.5 & 2.5 \\
Black pepper & 0.2 & 0.2 & 0.2 & 0.2 & 0.2 \\
Sodium nitrite & 0.024 & 0.024 & 0.024 & 0.024 & 0.024 \\
\hline Total & 14.724 & 14.724 & 14.724 & 14.724 & 14.724 \\
\hline
\end{tabular}

${ }^{1}$ The salt-water was prepared by dissolving sodium chloride in distilled water and adjusting its salinity to $11.5 \%$ salt.

${ }^{2,3)}$ The juices released naturally from the salted and fermented anchovy (SFA) or shrimp (SFS) and their salinities were adjusted to $11.5 \%$ salt. 
Tecator AB, Höganas, Sweden).

\section{Warner-Bratzler shear force (WBSF) and texture property analysis (TPA)}

The samples were prepared as a uniform shape (1.0X $2.0 \times 0.3 \mathrm{~cm})$ for measurements of WBSF and TPA. An Instron Universal Testing Machine (Model 4400, Instron Co., USA) was used for analysis of WBSF (N). Its crosshead speed was $200 \mathrm{~mm} / \mathrm{min}$ and a $500 \mathrm{~N}$ load cell was applied. TPA including hardness $(\mathrm{N})$, cohesiveness (\%), and springiness (\%) was determined using a Rheo-meter (Compac-100, Sun Scientific Co., Japan). Force-time deformation curves were obtained with mode \#21 (Real), $200 \mathrm{~N}$ load cell, $2 \mathrm{~mm} / \mathrm{s}$ table speed, Rep. 2, and adapter area $5 \mathrm{~mm}$. Hardness, cohesiveness, and springiness were quantified as described by Bourne (1978).

\section{Surface color}

The surface color of the samples was measured, using a colorimeter (CR-300, Minolta Co., Japan) that was standardized with a white ceramic plate $(\mathrm{Y}=93.5, \mathrm{x}=0.3132$, $\mathrm{y}=0.3198$ ). Commission International d'Eclairage (CIE) $\mathrm{L}^{*}$ (lightness), $\mathrm{a}^{*}$ (redness), $\mathrm{b}^{*}$ (yellowness), chroma ((a*2 $\left.\left.+b^{* 2}\right)^{1 / 2}\right)$, and hue angle $\left(\tan ^{1}\left(b^{*} / a^{*}\right)\right)$ were observed.

\section{Sensory evaluation}

Sensory evaluation was performed by 12 panelists ( 5 females, 7 males, aged between 24 and 40 years) experienced in meat sensory evaluation. The panelists evaluated the beef jerky for color, flavor, odor, saltiness, tenderness and overall acceptability using a 9-point scale described by Meilgaard et al. (1999) as presented in Table 2. The panelists were seated in individual booths, and distilled water was used to cleanse the palate between the beef jerky samples (Keeton, 1983).

\section{Statistical analysis}

One-way analysis of variance (ANOVA) was used to evaluate the significance of differences of the obtained data, and Duncan's multiple range test was employed to determine the significance between treatments (SAS, 2002). All data are presented as means with standard deviation (SD) and a significance level of $p<0.05$ was used for statistical analysis of means from treatments.

\section{Results and Discussion}

\section{$\mathbf{a}_{\mathrm{w}}$ and $\mathrm{pH}$}

The results of $a_{w}$ are presented in Table 3 . The $a_{w}$ of beef
Table 2. Definitions and scale of sensory attributes evaluated

\begin{tabular}{|c|c|}
\hline Attribute & Definition \\
\hline $\begin{array}{l}\text { Color } \\
\text { 1=Extremely light } \\
\text { 9=Extremely dark }\end{array}$ & $\begin{array}{l}\text { Evaluate the intensity of } \\
\text { the gray color }\end{array}$ \\
\hline $\begin{array}{c}\text { Flavor } \\
1=\text { Extremely weak } \\
9=\text { Extremely strong }\end{array}$ & $\begin{array}{l}\text { The combination of taste and } \\
\text { tactile stimuli perceived while } \\
\text { chewing and swallowing }\end{array}$ \\
\hline $\begin{array}{c}\text { Odor } \\
1=\text { Extremely weak } \\
9=\text { Extremely strong }\end{array}$ & Intensity of overall odor \\
\hline $\begin{array}{c}\text { Saltiness } \\
1=\text { No salty taste } \\
9=\text { Extremely salty }\end{array}$ & Taste associated with sodium ions \\
\hline $\begin{array}{c}\text { Tenderness } \\
1=\text { Extremely tough } \\
9=\text { Extremely tender }\end{array}$ & $\begin{array}{l}\text { Minimum force required to cut } \\
\text { or chew the beef jerky sample }\end{array}$ \\
\hline $\begin{array}{l}\text { Overall acceptability } \\
\text { 1=Extremely undesirable } \\
9=\text { Extremely desirable }\end{array}$ & $\begin{array}{l}\text { The impression of preference for the } \\
\text { beef jerky considering the overall } \\
\text { sensory attributes evaluated }\end{array}$ \\
\hline
\end{tabular}

Table 3. Water activity $\left(a_{w}\right)$ and $\mathrm{pH}$ of beef jerky cured with salted and fermented anchovy and shrimp

\begin{tabular}{ccc}
\hline \hline Treatments $^{1)}$ & $\mathrm{a}_{\mathrm{w}}$ & $\mathrm{pH}$ \\
\hline $\mathrm{C}$ & $0.77 \pm 0.01^{\mathrm{b}}$ & $5.72 \pm 0.01^{\mathrm{c}}$ \\
$\mathrm{SFA} 1$ & $0.80 \pm 0.01^{\mathrm{a}}$ & $5.73 \pm 0.01^{\mathrm{c}}$ \\
$\mathrm{SFA2}$ & $0.80 \pm 0.01^{\mathrm{a}}$ & $5.75 \pm 0.01^{\mathrm{b}}$ \\
$\mathrm{SFS} 1$ & $0.81 \pm 0.01^{\mathrm{a}}$ & $5.79 \pm 0.02^{\mathrm{a}}$ \\
$\mathrm{SFS} 2$ & $0.81 \pm 0.01^{\mathrm{a}}$ & $5.79 \pm 0.01^{\mathrm{a}}$ \\
\hline
\end{tabular}

${ }^{\mathrm{a}-\mathrm{c}}$ Means $\pm \mathrm{SD}$ with different superscripts in the same column are significantly different $(p<0.05)$.

${ }^{1)}$ Treatments are the same as Table 1.

jerky was within the range of $0.77-0.81$. There were significant differences in $\mathrm{a}_{\mathrm{w}}$ among the treatments $(p<0.05)$. The $\mathrm{a}_{\mathrm{w}}$ of control jerky (C) was lower than those of other samples of beef jerky cured by SFA or SFS ( $p<0.05)$; however, there were no significant differences among the treatments except for $\mathrm{C}(p>0.05)$. Dried foods such as jerky are shelf-stable products stored at room temperature and consumed without additional cooking. Bacterial growth of jerky type products is primarily inhibited by lowering $\mathrm{a}_{\mathrm{w}}(<0.85)$ (Gailani and Fung, 1986). In the present study, all beef jerky had low $\mathrm{a}_{\mathrm{w}}(<0.80)$ and thus are stable for bacterial growth. However, SFF juices had the effect of increasing the $\mathrm{a}_{\mathrm{w}}$ of beef jerky. According to the previous reports on salted-fermented fish, free amino acids, amines, peptides, and other nitrogenous compounds were produced by fermentation of fish regardless of fish type and salt content (Cho et al., 1999, 2000; Mohamed et al., 2009; Peralta et al., 2008; Roseiro et al., 2008). Therefore, it is assumed that the relatively higher $\mathrm{a}_{\mathrm{w}}$ for SFF juice-treated beef jerky was caused by the various compounds of the 
SFF juice, such as amino acids, peptides, organic acids, and amines.

The $\mathrm{pH}$ values of beef jerky showed significant differences between treatments $(p<0.05)$ (Table 3$)$. C and SFA1 had the lowest $\mathrm{pH}$, while SFS1 and SFS2 hadthe highest $\mathrm{pH}$ values among the treatments $(p<0.05)$. As mentioned by Leistner (1987) and Ogahara et al. (1995), low pH can inhibit or delay the spoilage of various dried meat products by mold and microorganism growth. In the present study, the higher $\mathrm{pH}$ values of jerky cured by SFF juices are a result of the $\mathrm{pH}$ values of raw SFF juices. The $\mathrm{pH}$ of SFA and SFS juices were $5.51 \pm 0.02$ and $5.72 \pm 0.01$, respectively (not presented). From a shelf-stable point of view, some improvements in the salinity of the curing solution or in the processing condition such as drying time and temperature are needed.

\section{Moisture and protein contents}

Among the treatments, SFS1 and SFS2 were the highest in moisture content but the lowest in protein content $(p<0.05)$, as shown in Table 4. SFA1 and SFA2, on the other hand, had lower moisture content and higher protein content than the other treatments $(p<0.05)$. The moisture and protein contents of beef jerky were within the range of $23.52-27.04 \%$ and $64.41-67.56 \%$, respectively. $a_{w}$ is closely related to moisture content in meat products, so it is important to control the moisture content (Leistner, 1987). In the present study, beef jerky cured by SFS juice, regardless of SFS juice level, had higher moisture content and $\mathrm{a}_{\mathrm{w}}$ than $\mathrm{C}, \mathrm{SFA1}$, and SFA2. However, $\mathrm{C}$ had the lowest $\mathrm{a}_{\mathrm{w}}$ among the treatments, but its moisture content was not lower than those of SFA1 and SFA2. Although the salinity is the same between salt-water and SFF juices, in the making of beef jerky, the $\mathrm{a}_{\mathrm{w}}$ as well as moisture content of other components that consist of SFF juices could be affected.Moreover, SFF juice has nitrogenous compounds as well as various microorganisms (Jung et al., 2005; Mah et al., 2008; Park et al., 2010). Microorganisms and their products may be affected moisture content and $\mathrm{a}_{\mathrm{w}}$, additional researches are needed.

The moisture-to-protein ratio (MPR) value in raw beef is on average 4.5, but for purposes of microbial safety, that in jerky type productscannot exceed 0.75 (USDA, 1996). MPR ranged from 0.35 to 0.42 , as shown in Table 4. Jerky-type snack foods are classified as intermediatemoisture foods, which exhibit proteincontent of $50 \%$, a low fat content (approximately 3.6\%), relatively high salt content (approximately 6.0\%), a low water content (2025\%), and $\mathrm{a}_{\mathrm{w}}$ below 0.8 (Chen et al., 2002; Konieczny et al., 2007; Labuza et al., 1970). The beef jerky cured with SFFs presented low moisture content (23.52-27.04\%) and $64.41-66.83 \%$ of protein content, thus they exhibited low MPR values below 0.75 .

\section{WBSF and TPA}

The results of WBSF and TPA, including hardness, cohesiveness, and springiness, are presented in Table 5. The beef jerky cured with SFS showed lower WBSF than C

Table 4. Moisture, protein content, and moisture-to-protein ratio of beef jerky cured with salted and fermented anchovy and shrimp

\begin{tabular}{cccc}
\hline \hline Treatments $^{\mathrm{I}}$ & Moisture content (\%) & Protein content (\%) & Moisture-to-protein ratio (MPR) \\
\hline C & $25.32 \pm 0.31^{\mathrm{b}}$ & $66.22 \pm 0.42^{\mathrm{b}}$ & 0.38 \\
SFA1 & $23.52 \pm 0.26^{\mathrm{c}}$ & $66.83 \pm 0.31^{\mathrm{ab}}$ & 0.35 \\
SFA2 & $23.77 \pm 0.17^{\mathrm{c}}$ & $67.56 \pm 0.49^{\mathrm{a}}$ & 0.35 \\
SFS1 & $26.71 \pm 0.41^{\mathrm{a}}$ & $64.57 \pm 0.54^{\mathrm{c}}$ & 0.41 \\
SFS2 & $27.04 \pm 0.35^{\mathrm{a}}$ & $64.41 \pm 0.55^{\mathrm{c}}$ & 0.42 \\
\hline
\end{tabular}

${ }^{a-c}$ Means \pm SD with different superscripts in the same column are significantly different $(p<0.05)$.

${ }^{1)}$ Treatments are the same as Table 1.

Table 5. Warner-Bratzler shear force (WBSF), hardness, cohesiveness, and springiness of beef jerky cured with salted and fermented anchovy and shrimp

\begin{tabular}{ccccc}
\hline \hline Treatments $^{1)}$ & WBSF & Hardness (N) & Cohesiveness (\%) & Springiness (\%) \\
\hline C & $84.48 \pm 1.47^{\mathrm{a}}$ & $100.85 \pm 4.97^{\mathrm{a}}$ & $16.78 \pm 1.30^{\mathrm{d}}$ & $80.30 \pm 1.67^{\mathrm{b}}$ \\
SFA1 & $83.79 \pm 3.43^{\mathrm{a}}$ & $82.52 \pm 2.50^{\mathrm{c}}$ & $26.24 \pm 1.59^{\mathrm{a}}$ & $57.25 \pm 2.25^{\mathrm{b}}$ \\
SFA2 & $83.69 \pm 1.08^{\mathrm{a}}$ & $89.62 \pm 2.42^{\mathrm{b}}$ & $21.67 \pm 0.83^{\mathrm{c}}$ & $72.96 \pm 6.82^{\mathrm{a}}$ \\
SFS1 & $65.56 \pm 2.45^{\mathrm{b}}$ & $82.09 \pm 1.32^{\mathrm{cd}}$ & $23.92 \pm 1.05^{\mathrm{b}}$ & $53.24 \pm 2.43^{\mathrm{b}}$ \\
SFS2 & $68.01 \pm 5.44^{\mathrm{b}}$ & $77.92 \pm 2.36^{\mathrm{d}}$ & $22.57 \pm 1.57^{\mathrm{bc}}$ & $77.26 \pm 2.19^{\mathrm{a}}$ \\
\hline
\end{tabular}

\footnotetext{
${ }^{a-d}$ Means \pm SD with different superscripts in the same column are significantly different $(p<0.05)$.
}

${ }^{1)}$ Treatments are the same as Table 1. 
$(p<0.05)$, whereas the beef jerky cured with SFA did not exhibit any significant difference from $\mathrm{C}(p>0.05)$. Among the treatments, $\mathrm{C}$ had the highest value of hardness $(p<$ 0.05); however, other TPAs such as cohesiveness and springiness were lowest in $\mathrm{C}(p<0.05)$. SFS1 and SFS2 had the lowest hardness as the result of WBSF $(p<0.05)$. These results agree with the previous report that WBSF or hardness is affected by moisture content (Yang et al., 2012). It is considered that various compounds which resulted from the fermentation of fish (Cho et al., 1999, 2000; Mohamed et al., 2009; Peralta et al., 2008; Roseiro et al., 2008) also affected WBSF and TPA of beef jerky. In the results of cohesiveness and springiness, totalreplacement of salt-water with SFA had the effect of causing a decrease in the cohesiveness of beef jerky, but an increase in springiness. The same effect of SFS was also found in the springiness of SPS1 and SPS2, but not in cohesiveness. Therefore, curing with SFS could decrease the WBSF of the beef jerky, and both SFA and SFS are effective for improving the TPA of the beef jerky regardless the level of SFFs. Furthermore, total replacement with SFFs could affect the increase in springiness of the beef jerky.

\section{Surface color}

The results for surface color of the beef jerky are shown in Table 6. As expected, $\mathrm{C}$ had the highest values of all surface color traits $(p<0.05)$ and only SFA1 did not show significant differences in lightness $\left(\mathrm{L}^{*}\right)$, and hue angle with C ( $p>0.05)$. SFA decreased the redness ( $\left.a^{*}\right)$, yellowness $\left(b^{*}\right)$ and chroma of beef jerky according to the level of replacement $(\mathrm{C}>\mathrm{SFA} 1>\mathrm{SFA} 2)$. However, there were no significant differences in all color measurements except for $\mathrm{L}^{*}$ between SFS1 and SFS2 $(p>0.05)$. Other studies have reported that $\mathrm{L}^{*}, \mathrm{a}^{*}$, and $\mathrm{b}^{*}$ of general beef jerky exhibited the range of 22.85-31.12, 10.2-11.96, and 4.5210.8, respectively (Konieczny et al., 2007; Sindelar et al., 2010; Yang et al., 2009). According to Konieczny et al. (2007), surface color values of beef jerky can change according to the drying time at the same temperature, i.e., Hunter L-value decreased and a-value increased with increase of drying time from 0 to $7 \mathrm{~h}$. However, in the present study, because the same drying conditions, such as temperature $\left(70^{\circ} \mathrm{C}\right)$ and time $(6 \mathrm{~h})$, were applied to the treatments, the effect of color change was caused by SFFs. The brown color intensity of salt-fermented shrimp pastes increased with increase of the fermentation period (Peralta et al., 2008). In the present study, SFFs caused a steep decrease in the surface color values, especially $a^{*}, b^{*}$, and chroma. Those samples of the beef jerky replaced with $50 \%$ SFS (SFS1) and 100\% SFS (SFS2) and SFA (SFA2) decreased to be less than half of $\mathrm{a}^{*}, \mathrm{~b}^{*}$, and chroma of $\mathrm{C}$.

\section{Sensory evaluation}

As presented in Table 7, color, flavor, saltiness and overall acceptability were significantly different between treatments in sensory evaluation $(p<0.05)$. The color of

Table 6. Surface color of beef jerky cured with salted and fermented anchovy and shrimp

\begin{tabular}{|c|c|c|c|c|c|}
\hline \multirow{2}{*}{ Traits } & \multicolumn{5}{|c|}{ Treatments ${ }^{1)}$} \\
\hline & $\mathrm{C}$ & SFA1 & SFA2 & SFS1 & SFS2 \\
\hline Lightness $\left(\mathrm{L}^{*}\right)$ & $25.21 \pm 0.67^{\mathrm{a}}$ & $24.41 \pm 0.30^{\mathrm{ab}}$ & $23.81 \pm 0.37^{b}$ & $23.37 \pm 0.35^{\mathrm{b}}$ & $20.82 \pm 0.30^{\mathrm{c}}$ \\
\hline Redness (a*) & $9.72 \pm 0.44^{\mathrm{a}}$ & $7.99 \pm 0.73^{\mathrm{b}}$ & $4.77 \pm 0.13^{\mathrm{c}}$ & $4.42 \pm 0.39^{c}$ & $4.52 \pm 0.26^{\mathrm{c}}$ \\
\hline Yellowness $\left(b^{*}\right)$ & $2.55 \pm 0.22^{\mathrm{a}}$ & $1.76 \pm 0.35^{\mathrm{b}}$ & $1.15 \pm 0.05^{\mathrm{c}}$ & $0.88 \pm 0.11^{\mathrm{cd}}$ & $0.77 \pm 0.01^{\mathrm{d}}$ \\
\hline Chroma & $10.04 \pm 0.48^{\mathrm{a}}$ & $8.17 \pm 0.78^{b}$ & $4.90 \pm 0.12^{\mathrm{c}}$ & $4.50 \pm 0.4^{\mathrm{c}}$ & $4.58 \pm 0.26^{\mathrm{c}}$ \\
\hline Hue & $14.60 \pm 0.62^{\mathrm{a}}$ & $12.27 \pm 1.44^{\mathrm{ab}}$ & $13.43 \pm 0.93^{b c}$ & $11.13 \pm 0.38^{\mathrm{cd}}$ & $9.60 \pm 0.44^{\mathrm{c}}$ \\
\hline
\end{tabular}

${ }^{\mathrm{a}-\mathrm{d}}$ Means $\pm \mathrm{SD}$ with different superscripts in the same row are significantly different $(p<0.05)$.

${ }^{1)}$ Treatments are the same as Table 1.

Table 7. Sensory evaluation of beef jerky cured with salted and fermented anchovy and shrimp

\begin{tabular}{clllll}
\hline \hline Traits & \multicolumn{5}{c}{ Treatments } \\
\cline { 2 - 6 } & \multicolumn{1}{c}{ C } & SFA1 & \multicolumn{1}{c}{ SFA2 } & SFS1 & SFS2 \\
\hline Color & $4.33 \pm 0.52^{\mathrm{b}}$ & $4.40 \pm 0.89^{\mathrm{b}}$ & $5.80 \pm 0.45^{\mathrm{a}}$ & $5.83 \pm 0.41^{\mathrm{a}}$ & $6.50 \pm 0.55^{\mathrm{a}}$ \\
Flavor & $4.17 \pm 0.98^{\mathrm{c}}$ & $5.50 \pm 0.55^{\mathrm{ab}}$ & $5.50 \pm 1.00^{\mathrm{ab}}$ & $5.40 \pm 0.55^{\mathrm{ab}}$ & $6.00 \pm 0.82^{\mathrm{a}}$ \\
Odor & $1.03 \pm 0.18$ & $1.10 \pm 0.15$ & $1.17 \pm 0.16$ & $1.20 \pm 0.18$ & $1.22 \pm 0.14$ \\
Saltiness & $6.25 \pm 0.50^{\mathrm{a}}$ & $6.33 \pm 0.52^{\mathrm{a}}$ & $5.20 \pm 0.45^{\mathrm{b}}$ & $5.17 \pm 0.41^{\mathrm{b}}$ & $5.40 \pm 0.55^{\mathrm{b}}$ \\
Tenderness & $5.45 \pm 0.56$ & $5.53 \pm 0.41$ & $5.75 \pm 0.56$ & $5.98 \pm 0.50$ & $5.82 \pm 0.36$ \\
Overall acceptability & $5.38 \pm 0.23^{\mathrm{bc}}$ & $5.20 \pm 0.30^{\mathrm{c}}$ & $5.75 \pm 0.42^{\mathrm{ab}}$ & $5.50 \pm 0.25^{\mathrm{b}}$ & $6.05 \pm 0.35^{\mathrm{a}}$ \\
\hline
\end{tabular}

${ }^{\mathrm{a}-\mathrm{c}}$ Means $\pm \mathrm{SD}$ with different superscripts in the same row are significantly different $(p<0.05)$.

${ }^{1)}$ Treatments are the same as Table 1. 
beef jerky showed a similar trend with the result of surface color (instrumental analysis). Curing with SFA and SFS brought about decreases in all surface color measurements as shown in Table 7. In the result of sensory evaluation, the beef jerky cured with $50 \%$ of SFS (SFS1) and $100 \%$ SFA (SFA2) and SFS (SFS2) was darker than C $(p<0.05)$. Flavor values for treatments cured with SFFs were significantly higher than that for $\mathrm{C}(p<0.05)$. The SFFs contain various compounds, such as amino acids, peptides, and nitrogenous substance, because the fish fermentation process induces the transformation of organic substances to various simpler compounds, which are the origins of their unique flavors and aromas (Peralta et al., 2008; Tsai et al., 2006). In the present study, these unique flavors and aromas from SFFs played a positive role in the sensory properties of the beef jerky. Saltiness was higher in C and SFA1 than in SFA2, SFS1, and SFS2 $(p<$ 0.05 ). Salt is a major ingredient for the food industry and it helps to enhance the flavor intensity of foods (Batenburg and van der Velden, 2011; Wirth, 1989). Among the various amino acids, it is known that arginine is a good contributor to the salty taste (Breslin and Beauchamp, 1997; Ogawa et al., 2004). In the present study, the various compounds from SFFs enhanced the flavor of the beef jerky; however, they had the effect of reducing the saltiness of the beef jerky. Among the treatments,overall acceptability was the highest in SFS2 $(p<0.05)$, whereas SFA1 showed the lowest overall acceptability $(p<0.05)$ because of low color and high saltiness values.

\section{Conclusions}

The SFFs improved the texture and sensory properties of the beef jerky, but negative effects were found in $\mathrm{a}_{w}$, $\mathrm{pH}$, and surface color. The compounds from SFFs could be good enhancers for the flavor of the beef jerky. Overall, the beef jerky cured with $100 \%$ SFS exhibited good WBSF, TPA, and sensory properties. However, studies are still needed on improving the $\mathrm{a}_{\mathrm{w}}, \mathrm{pH}$, and surface color of the beef jerky to apply the SFFs for making beef jerky.

\section{Acknowledgements}

This work was supported by IPET project (No. 1130273), Ministry for Agriculture, Food and Rural Affairs, Republic of Korea. E. Y. Jung, H. J. Lim and H. W. Seo were supported by the Brain Korea 21 Plus Project from the Ministry of Education and Human Resources Development, Republic of Korea.

\section{References}

1. Adams, M. R., Cooke, R. D., and Rattagool, P. (1985) Fermented fish products of South East Asia. Tropical Sci. 25, 61-73.

2. Albright, S. N., Kendall, P. A., Avens, J. S., and Sofos, J. N. (2003) Pretreatment effect on inactivation of Escherichia coli O157:H7 inoculated beef jerky. LWT-Food Sci.Technol. 36, 381-389.

3. AOAC (2000) Official methods of analysis (18th ed.). Association of Official Analytical Chemists, Washington, DC, p. 931.

4. Batenburg, M. and van der Velden, R. (2011) Saltiness enhancement by savory aroma compounds. J. Food Sci. 76, S280S288.

5. Bourne, M. C. (1978) Texture profile analysis. Food Technol. 32, 62-72.

6. Breslin, P. A. and Beauchamp, G. K. (1997) Salt enhances flavour by suppressing bitterness. Nature 387, 563.

7. Calicioglu, M., Sofos, J. N., and Kendall, P. A. (2003) Fate of acid-adapted and nonadapted Esherichiaa coli O157:H7 inoculated post-drying on beef jerky treated with marinades before drying. Food Microbiol. 20, 169-177.

8. Chen, W. S., Lin, D. C., and Chen, M. T. (2002) Determination of quality changes throughout processing steps in Chinese-style pork jerky. Asian Australas J. An. Sci. 17, 700-704.

9. Cho, Y. J., Im, Y. S., Lee, K. W., Kim, K. B., and Choi, Y. J. (1999) Change of components in salt-fermented northern sand lance, Ammodytes personatus sauce during fermentation. $J$. Korean Fish. Soc. 32, 693-698.

10. Cho, Y. J., Im, Y. S., Lee, K. W., Kim, K. B., and Choi, Y. J. (2000) Change of components in salt-fermented anchovy, Engraulis japonicas sauce during fermentation. J. Korean Fish. Soc. 33, 9-15.

11. Choi, J. H., Jeong, J. Y., Han, D. J., Choi, Y. S., Kim, H. Y., Lee, M. A., Lee, E. S., Paik, H. D., and Kim, C. J. (2006) Effects of pork/beef levels and various casings on quality properties of semi-dried jerky. Meat Sci. 80, 278-286.

12. Gailani, M. B. and Fung, D. Y. C. (1986) Critical review of water activities and microbiology of drying of meats. Crit. Rev. Food Sci. Nutr. 25, 159-183.

13. Han, D. J., Jeong, J. Y., Choi, J. H., Choi, Y. S., Kim, H. Y., Lee, M. A., Lee, E. S., Paik, H. D., and Kim, C. J. (2007) Effects of drying conditions on quality properties of pork jerky. Korean J. Food Sci. An. 27, 29-34.

14. Ishige, N. (1993) Cultural aspects of fermented fish products in Asia, In: Lee, C. H., Steinkraus, K. H., Reilly, P. J. A. (Eds.), Fish Fermentation Technology. United Nations University Press, Tokyo, pp. 13-32.

15. Jung, S. Y., Lee, M. H., Oh, T. K., Park, Y. H., and Yoon, J. H. (2005) Psychrobacter cibariussp. nov., isolated from jeotgal, a traditional Korean fermented seafood. Int. J. Syst. Evol. Microbiol. 55, 577-582.

16. Keeton, J. T. (1983) Effect of fat and $\mathrm{NaCl} /$ phosphate levels on the chemical and sensory properties of pork patties. J. Food Sci. 48, 878-881. 
17. Konieczny, P., Stangierski, J., and Kijowski, J. (2007) Physical and chemical characteristics and acceptability of home style beef jerky. Meat Sci. 76, 253-257.

18. Kuda, T., Izawa, Y., Ishii, S., Takahashi, H., Torido, Y., and Kimura, B. (2012) Suppressive effect of Tetragenococcus halophilus, isolated from fish-nukazuke, on histamine accumulation in salted and fermented fish. Food Chem. 130, 569-574.

19. Labuza, T. P., Tannenbaum, S. R., and Karel, M. (1970) Water content and stability of low-moisture and intermediate-moisture foods. Food Technol. 24, 543-550.

20. Leistner, L. (1987) Shelf-stable products and intermediate moisture foods based on meat. In: Water activity: Theory and applications to foods. Rocklang, L. B., Beuchat, L. R. (ed). Marcel Dekker, NY, pp. 295-328.

21. Mah, J. H., Han, H. K., Oh, Y. J., Kim, M. G., and Hwang, H. J. (2002) Biogenic amines in Jeotkals, Korean salted and fermented fish products. Food Chem. 79, 239-243.

22. Mah, J. H., Chang, Y. H., and Hwang, H. J. (2008) Paenibacillus tyraminigenes $\mathrm{sp}$. nov.isolated from Myeolchi-jeotgal, a traditional Korean salted and fermented anchovy. Int. J. Food Microbiol. 127, 209-214.

23. Meilgaard, M., Civille, G. V., and Carr, B. T. (1999) Sensory evaluation techniques. 3rd ed. Boca Ration, FL: CRC Press, pp. 354.

24. Mohamed, R., Livia, S. S., Hassan, S., Soher, E., and AhmedAdel, E. B. (2009) Changes in free amino acids and biogenic amines of Egyptian salted-fermented fish (Feseekh) during ripening and storage. Food Chem. 115, 635-638.

25. Ogahara, T., Ohno, M., Takayama, M., Igarashi, K., and Kobayashi, H. (1995). Accumulation of glutamate by osmotically stressed Escherichia coli is dependent pH. J. Bacteriol. 177, 5987-5990.

26. Ogawa, T., Nakamura, T., Tsuji, E., Miyanaga, Y., Nakagawa, H., Hirabayashi, H., and Uchida, T. (2004) The combination effect of L-Arginine and $\mathrm{NaCl}$ on bitterness. Chem. Pharm. Bull. 52, 172-177.

27. Park, E. J., Kim, M. S., Roh, S. W., Jung, M. J., and Bae, J. W. (2010) Kocuria atrinae sp. nov., isolated from traditional Korean fermented seafood. Int. J. Syst. Evol. Microbiol. 60,
914-918.

28. Peralta, E. M., Hatate, H., Kawabe, D., Kuwahara, R., Wakamatsu, S., Yuki, T., and Murata, H. (2008) Improving antioxidant activity and nutritional components of Philippine saltfermented shrimp paste through prolonged fermentation. Food Chem. 111, 72-77.

29. Roseiro, L., Santos, C., Sol, M., Borges, M., Anjos, M., and Gon alves, H. (2008) Proteolysis in Painho de Portalegre dry fermented sausage in relation to ripening time and salt content. Meat Sci. 79, 784-794.

30. SAS. (2002) SAS/STAT User's Guide, Version 8.2. Cary, NC: SAS Institute Inc.

31. Sindelar, J. J., Terns, M. J., Meyn, E., Boles, and J. A. (2010) Development of a method to manufacture uncured, no-nitrate/ nitrite-added whole muscle jerky. Meat Sci. 86, 298-303.

32. Tsai, Y. H., Lin, C. Y., Chien, L. T., Lee, T. M., Wei, C. I., and Hwang, D. F. (2006) Histamine contents of fermented fish products in Taiwan and isolation of histamine-forming bacteria. Food Chem. 98, 64-70.

33. USDA. (1996) Food safety and inspection service, meat and poultry inspection technical services, standards and labeling division. Standards and labeling policy book. Washington, DC.

34. Wirth, F. (1989) Reducing the common salt content of meat products: Possible methods and their limitations. Fleischwirtschaft 69, 589-593.

35. Yang, H. S., Hwang, Y. H., Joo, S. T., and Park, G. B. (2009) The physicochemical and microbiological characteristics of pork jerky in comparison to beef jerky. Meat Sci. 82, 289294.

36. Yang, H. S., Kang, S. W., Joo, S. T., and Choi, S. G. (2012) Effects of salt concentration and drying time on the quality characteristics of pork jerky during dehydration. Korean $J$. Food Sci. An. 32, 285-292.

37. Zeng, X., Xia, W., Jiang, Q., and Yang, F. (2013) Chemical and microbial properties of Chinese traditional low-salt fermented whole fish product Suan yu. Food Control 30, 590595.

$\overline{\text { (Received 2013.9.3/Revised 2013.12.23/Accepted 2014.1.24) }}$ 